VIII.1, Winter 1986 Informal Logic

\title{
The Argumentum Ad Adversarium
}

\author{
JOHN MCMURTRY University of Guelph
}

\section{Introduction}

The fallacy of ignoratio elenchi ("ignorance of the argument") comes in many forms. The traditional species are marked by a Latin nomenclature: the ad hominem ("to the man"), ad baculum ("to force"), ad misericordiam ("to pity"), ad populum ("to the people") and ad verecundiam ("to reverence" or "authority).[1] The common principle underlying these and all other types of the ignoratio elenchi is that each diverts the argument onto a premise that is irrelevant to the claim in contention. Because they are familiar and recognizable kinds of dishonest argumentation-in particular, the appeals ad hominem and ad baculum which are a stock-in-trade of everyday communication and exchange-they are widely enshrined as fallacies in informal logic courses and texts. Indeed knowledge of the ad hominem has achieved such wide currency that it has passed into the language as a more or less standard term of literate discourse.

What I wish to propose here is that there is a kind of ignoratio elenchi so far unrecognized which is as easily identifiable and more influentially misleading than the traditional types, but which has as yet escaped a name to detect it. This kind, as all others of its species, diverts argument onto an irrelevant premise, but it does so in a special way: by rerouting discussion onto the alleged property or behaviour of a common adversary.[2]

For example, a government or its leadership might attempt to counter the argument that it has broken a law, harmed innocents or lied, by diverting the attack on it into a well-known enemy with no demonstrable connection to the wrongdoing alleged-a national adversary (e.g. "communists", "subversives") or some other opposition group against whom there is activatable hostility. Critical attention is thereby directed away from its original object, the government or its leadership, and onto another target.

What makes this move of argument a fallacy is that it does not address the question at hand, but evades it by digression onto another topic. What allows it to succeed in this digression is that it strikes at a ready-made adversary whom the audience has a current disposition to attack. Because this sort of counter does not answer to the claim or argument raised, or establish its truth or falsity one way or the other, it is "beside" the point, a move to an irrelevant premise.

We will call this form of diversionary move the argumentum ad adversarium fallacy.

The argumentum ad adversarium may be used to waylay almost any kind of discussion, but is paradigmatically used to deflect criticism of regime wrongdoing. We can observe its operation daily. For example, the Reagan administration of the United States has consistently appealed to the ad adversarium in stock response to domestic and allied criticism of its policies in various countries of the third world, regularly diverting the argument onto 
denunciation of the Soviet Union, a common adversary that can be counted on to be opposed by domestic and allied audiences. The issue is in this way altered from the U.S. government's alleged support of dictatorial governments or multinational exploitation of impoverished peoples to the "totalitarianism", "international terrorism", and so on of a conventional enemy.

This pattern of digression is not tu quoque, for it is not turned against the critic ("you too"), but against a common adversary of the audience including the critic. Moreover, because its diversion is onto a customarily shared opponent, protest against its legitimacy can be retaliatively interpreted as tantamount to harbouring the case of the enemy itself. These special features of the ad adversarium fallacy make it a very powerful device of mass propaganda and political manipulation.

\section{Specific Examples of the Ad Adversarium}

The following are examples of the ad adversarium's use:

(1) After two World Court decisions in May, 1984, by majorities of 15 to 0 and 14-1 in support of Nicaragua's complaint against U.S. direction and support of armed attacks against Nicaragua in violation of international law, the Reagan administration rejected the Court's decision as "political" (though 5 allied and 2 U.S. judges voted for the judgement). Spokesmen for the administration then affirmed the "U.S. government's right not to break faith with those who are risking their lives on every continent - from Afghannistan to Nicaragua - to defy Sovietsupported aggression". [3]

(2) In reply to reporters' questions about alleged C.I.A. support of the Khalistan National Front (a Sikh separatist movement later linked to the assassination of Indira Candhi), a senior counsellor for the Khalistan Front replied, "They might help us in the near future ... They have to help us stop communism". [4]
(3) Speaking against a City of Toronto proposal to let contracts only to companies that offer equal opportunity employment, Alderman Anthony $\mathrm{O}^{\prime}$ Donohue attacked the report as a "McCarthy-type program" that must be rejected by City Council.[5]

(4) In a widely published letter to Ontario Attorney-General Ian Scott, evangelical activist Rev. Kenneth Campbell argued that the Morgentaler Clinic of Toronto ought to be forcibly closed because "behind its benign facade lurks the same ugly spirit as fuelled the flames of Hitler's ultimate solution to the 'Jewish problem' at Auschwitz".[6]

In all these cases, a diversion from the issue at hand is achieved by attack on a commonly recognized and even hated adversary of the audience"political" machinations, "Soviet supported aggression", "communism", "McCarthy type" programs and "Hitler's final solution". In no case do the premises about the selected adversary, even if correct, tell for or against the position in question. They have no demonstrated relationship to the issue under debate. But because the ad adversarium satisfies a deepseated propensity to attack objects of common enmity, its irrelevant appeal has an infra-rational power to draw its audience into red-herring pursuit.

\section{Distinctions between the Ad Adversarium and Other Fallacies}

It might be thought that the ad adversarium fallacy is a species of the ad populum, the appeal "to the people" $^{\prime \prime}$. But this classification would overlook two crucial distinctions. First of all, the ad adversarium diverts attention to that which is posed against the people, not to what they are for. The nature of its appeal, then, is the opposite of the ad populum, and to the extent that people are more inclined to be incited to attack what they are against than support what they are for, more likely to dupe them into digression.

Secondly, the digression of the ad- 
populum lies in the reason it produces for its conclusion-that because $Q$ is widely accepted, $\mathbf{Q}$ is true. On the other hand, the irrelevance of the ad adversarium is more radical. It diverts the argument onto another issue, changing the topic from the truth or falsity of $\mathbf{Q}$, to attack on a common adversary whose relationship to $\mathbf{Q}$ is non-existent or not shown.

We might also distinguish the ad adversarium from the "smear" or guilt-by-association technique. The most obvious difference is that the latter fallacies do not direct their audiences to a common adversary, but to a bearer of social contagion. But since such a bearer may not be an adversary, nor the common adversary be such a bearer, the two kinds of diversionary object are quite distinct. More fundamentally, there is a basic distinction between these fallacies' structures of diversion. The 'guilt by association' or 'smear' tactic works by means of an alleged relationship between the position it seeks to discredit and an already discredited position. The ad adversarium, in contrast, diverts to a common foe with no such linkage of positions necessary to its move. Its fallacy is not one of concluding too much from a claimed likeness or association.

Consider the following example. The long-time President of the Philippines, Ferdinand Marcos, facing heavy political fire prior to the first presidential elections for many years under his martial-law government, was accused of "fraudulent" pretence to a heroic war record. The documented charge was particularly embarrassing because it came from his most powerful ally, the U.S. Army, and was published through the normally friendly U.S. media. Marcos's reply to the charge was to attack a common adversary who had no possible association with his accusers, and thus no capacity for a transfer of "smear" or "guilt" onto them. "Those who collaborated with the enemy", he replied to the charge, "have no right to question the role of the guerillas during the war". [7] $^{\prime \prime}$ We can see here that the ad adversa- rium diversion may be deployed with no connective link at all to the issue at hand.

It is worth noting, however, that the 'smear' and 'guilt by association' techniques work best when they invoke a common adversary. For example, the celebrated 1950's "smear" tactic we know as "McCarthyism" depended for its special effectiveness on the audience's died-in-the-wool opposition to a perceived common enemy, the "communist menace". As with other fallacies, the ad adversarium move here is deployed as the means of distraction to mislead argument in a particular way. Virtually all fallacies have such an ad adversarium variant, one which appeals to an object of common enmity to lure its audience into its own train of illogic. This general deployment of the ad adversarium device bears watching as much as its "pure" expressions in an independently functioning form. We shall have more to say about the underlying power of the ad adversarium move in the last sections of this paper.

Still again, the ad adversarium fallacy may seem to be, but is not, a form of scapegoating. The "scapegoat" is an innocent sacrificial object under the control of those who victimize it, and used as a substitute object to shoulder their guilt. The common adversary, in contract, is none of these things. It is precisely an opposing, independent force, not a vicarious substitute. The more perceived it is as the contrary of controlled and defenseless - as threatening and aggressivethe more effective it is as an object to divert attention to. This is not to say that people do not misuse the concept of scapegoat to refer to what is, in truth, the ad adversarium diversion. But this misuse is apt to occur because the ad adversarium fallacy has not been identified to bear the necessary distinction.

Finally, it is important to distinguish the ad adversarium fallacy from the "two wrongs" fallacy it may in a different way appear to resemble. ("Don't blame me for $\mathbf{x}$, because $\mathbf{x}$ has been done by you or others".)[8] The 
essential difference here is that the "two wrongs" fallacy seeks to justify an alleged wrong by referring to a similar, known wrong elsewhere. In contrast, the ad adversarium fallacy requires only a diversion from an issue to a common adversary, who thereby becomes the object of focus. In distinction from the "two wrongs" fallacy, no wrong by the speaker is accepted or implied.

A striking example of the ad adversarium diversion recently occurred when the International Physicians for the Prevention of Nuclear War were awarded the Nobel Peace Prize in December 1985. "The prize has been betrayed", argued Aase Lionaes, a former chairman of the peace prize committee, and similar denunciations were repeated in the major media.[9] No supporting argument, however, was provided to show that any other candidate for the prize had worked more effectively than the 135,000 member organization of physicians in the quest for peace, or to demonstrate that the organization had failed to carry a truthful and impartial case for peace and nuclear disarmament across the world. The main point made by the host of critics of the winners of the award was that a founding member from the U.S.S.R. had 4 years previously signed a petition criticizing a Soviet dissident for his approval of U.S. plans to build the $M X$ missile. The issue was in this way switched from the qualifications of the 135,000 member body of the International Physicians for the peace award to the military threat and repressive internal policies of the Soviet Union. By thus diverting the discussion to a common adversary, the critics won almost universal Western media support in dismissing or downgrading the physicians' achievement.

The ad adversarium fallacy here does not allege "two wrongs", nor does it seek justification of a wrong by its speakers. Rather, it diverts the issue onto an easily-won point, the evils of a common enemy. Schematically put, the difference between the ad adversarium and "two wrongs" fallacy is as follows:

\begin{tabular}{lcc} 
Referent & $\begin{array}{c}\text { Two } \\
\text { Wrongs } \\
\text { Fallacy }\end{array}$ & $\begin{array}{c}\text { Ad Adver- } \\
\text { sarium } \\
\text { Fallacy }\end{array}$ \\
$\begin{array}{l}\text { two wrongs } \\
\text { alleged } \\
\text { wrong of a } \\
\text { common } \\
\text { adversary }\end{array}$ \\
$\begin{array}{l}\text { Similarity } \\
\text { of wrongs }\end{array}$ & asserted & $\begin{array}{c}\text { not } \\
\text { asserted }\end{array}$ \\
$\begin{array}{l}\text { Adversarial } \\
\text { relation- } \\
\text { ship to } \\
\text { audience }\end{array}$ & $\begin{array}{c}\text { none } \\
\text { required }\end{array}$ & required \\
$\begin{array}{l}\text { Logical } \\
\text { function } \\
\text { of fallacy }\end{array}$ & justifica- & tion \\
\hline
\end{tabular}

\section{The Question of Relevance}

In contrast to the cases we have so far considered, there are some situations in which reference to the properties or actions of a common adversary are not diversionary, but relevant. Consider the following case. Impoverished members of a third-world community are suffering under an economic order whose land, resources and capital are almost wholly owned by multinational corporations in partnership with a small domestic oligarchy: an economic order which is enforced by a rights-violating military directed and equipped by the same foreign power that owns the multinationals. Members of the exploited majority of this society might properly insist on discussing many or all of their political and economic problems in terms of a common adversary constituted of these three forces in alliance. Though a critic might be tempted to reject this move as yet another case of diverting the argument to attack on an alien "them", such a class-conflict analysis of the situation might be explanatorily appropriate and its proponents' reference 
to a common enemy as "behind" their various problems not irrelevant at all, but consistently pertinent and instructive.[10] How then do we distinguish between fallacious and non-fallacious cases of the ad adversarium move?

This is where the "deeper and more intensive" examination of an issue called for by Richard Paul in his article "Teaching Critical Thinking in the 'Strong' Sense", may be required.[11] In the various cases of the ad adversarium examined earlier, their fallacy of diversion was "atomically" evident without further exploration. Because they did not attempt to show the causal or logical relevance of the common enemy to whom critical discussion was redirected, their move was in each case fallacious on its face. In the example before us, on the other hand, no such disclosure of a fallacy is possible because the causal relevance of the common adversary to the economic and political plight of the community in question can be properly inferred from the very nature of the situation described. Given the accurate statement of these circumstances-monopoly ownership of land and resources, national origin of military assistance and equipment, violations of international norms of human right, and so on - the claim of a "common adversary" is not diversionary, but an explanatory generalization which reveals an underlying structure of occurrence. If a similar objective basis for directing discussion to a common adversary could be shown in any other case earlier judged fallacious-for example, for "Sovietsupported aggression" in Nicaragua to justify U.S. attacks upon it, or for "Hitler" and "Auschwitz" principles in voluntary abortion clinics - then the ad adversarium move would not be diversionary in these cases. In each instance, the move qualifies as relevant to the extent that these causal or logical connections are demonstrated, and, conversely, each counts as diversionary to the extent that such connections are not shown. The onus is on the sponsor of the ad adversarium move to prove the relevance of his claim. The principle for distinguishing the fallacious from the non-fallacious ad adversarium remains the same whether the argument can be spotted as diversionary at once (when there is no evidence of linkage to the issue in question), or whether it requires a deeper critical analysis to establish its diversionary or non-diversionary character (i.e. when there is an evident linkage whose sufficiency can only be ruled on after closer examination of the argument and its context of supporting claims). In sum, we can say that whether the ad adversarium fallacy is immediately or only mediately identifiable, it occurs when:

(1) Competing arguments or positions, $x, y, z$, are held with respect to an issue, $\mathbf{A}$;

(2) One or more of these arguments or positions, $\mathbf{x}, \mathbf{y}, \mathbf{z}$, refers to the properties or behaviour or a common adversary of the discussants and audience, $E$;

(3) $\mathbf{x}, \mathbf{y}$, or $\mathbf{z}$ fails to demonstrate that $\mathbf{E}^{\prime} s$ properties or behaviour is causally or logically relevant to $A$.

\section{The Universal Power and Mechanisms of the Ad Adversarium Appeal}

The fallacy of the ad adversarium is, of course, not confined to Western contexts. Other cultures have their own forms of diversion-onto-the-enemy too. For example, the government of the U.S.S.R. recurrently deflects criticism of its prosecution of free speech, or its movement of armies into neighbouring countries, by campaigns against "anti-Soviet propaganda", "U.S. imperialism", "anti-socialist sabotage" and so on. With these and other invocations of its audience's public adversary, the charges against the Soviet state's policies and actions are regularly distracted away from it, and onto the more easily winnable point of the evils of anti-patriotic forces. As with all such deployments of the ad 
adversarium ploy, the object of criticism, here the state administration of the U.S.S.R., both evades the need to respond with any relevant rebuttal, and, at the same time, provides its audience with an alternative object to discharge its hostility upon. As elsewhere, the former serves the ad adversarium's logical function of diversion, and the latter its psychological function of displacement. It is in this double-barrel appeal that the peculiar effectiveness of the ad adversarium fallacy lies.

The ad adversarium ploy need not only divert critical attention from its user to foreign adversaries, however. The common adversary can be domestic too, and even quite unrelated by the ad adversarium dodge to a national foe. For example, representatives of a political party can use the ad adversarium stratagem against critics by playing upon strongly opposed positions on quite other issues than what is under discussion. For example, in the months of October and November of 1985 , the governing Conservative Party of Canada met televised House of Commons criticisms of its over $\$ 1$ billion expenditure during a time of claimed austerity on bailing out two failed banks (the Canadian Commercial and the Northlands) with the argument that the previous Trudeau administration's National Energy Plan had "ruined Western Canada's prosperity". No evidence was presented to demonstrate this claim, nor was any argument given as to why this has any relevance to justifying a handout of over $\$ 1$ billion of public money to private banks and their major depositors (i.e. those with over $\$ 60,000$ accounts). Yet because "its game is not named", no report of these Parliamentary proceedings nor even opposition member protested the fallacy of diversion used. The common adversary, here a widely disliked former Prime Minister and his "socialist" policies regarding national control of oil supplies, was successfully invoked to distract the audience of these proceedings away from the issue in contention, and any need to answer or to refute it

The argumentum ad adversarium is in these ways a more profoundly beguiling form of the ignoratio elenchi than other known types. It is not only specially undetected as a fallacy, but it enlists on its behalf an audience appeal that trades on a very basic premise with which people tend to identify strongly-namely, the blameworthiness of a commonly accepted adversary, whatever or whoever it might be.

The most compelling advantage of the argumentum ad adversarium fallacy derives from the us-then moral opposition upon which its appeal is based. If the critic of, say, one's own or an ally's state terrorism presses his criticism after the argumentum ad adversarium has already been deployed to divert the issue onto the irrelevant premise of the evil doings of a common enemy elsewhere, then the critic lays himself (or herself) open to the charge that he/she is defending the behaviour of this common enemy by not acquiescing in the diversion. The offensive is thus transferred to the side of the invoker of the ad adversarium ruse, and the defensive is left to the pursuer of relevance of claim, who may be baited with a derivative ad hominem as well. "Why does he (or she) refuse to denounce the known evils of the enemy?" it may be asked. Why does he or she insist on "taking the enemy's side"? There are many possible variations on the referent of "other side" here"the communists", "terrorists", "subversives", "foreign infidels", "counter-revolutionaries", "outside agitators", "bourgeoisies", "Papists", and so on. But each's successful use as a diversionary object depends on the sociohistorical context in question, and who is a ready-made adversary within it. The tactical power of the ad adversarium appeal is that it redraws the lines of battle, and in such a way that its user is put on the offensive and the side of the good, and its critic is put on the defensive and the side of the bad.

This reversal may be the most effect- 
ive manageable by any form of fallacy because it directly mobilizes the infra structure of group self-constitution, negation of the Other, against the argument opponent. The argumentum ad adversarium is irrational because it is irrelevant, but it is misleading in such a way as to run beneath reason in its primordial appeal. This is perhaps why it has remained so long unflagged as an argument strategy. The us-them lines of affirmation and rejection to which it reverts are by their very depth of social presupposition the most advantageous lines on which to defend one's own position and depose another's. For they are the underlying lines of defense and attack of the group itself, within whose audience arguments are taken up as creditable or repudiated as wrong.

The ad adversarium fallacy does, however, admit of degrees of power in its diversionary enticement. For this reason, we propose a general principle of proportionality governing the ad adversarium's appeal. Given its nonrecognition as a fallacy, the more commonly and intensely repudiated the adversary is at the time the argumentum ad adversarium is deployed, the more this fallacy is likely to succeed in holding the argument on irrelevant ground.

This "law of proportionality" is complemented by a second principle of the ad adversarium's successful operation which functions to maintain the first intact. That is, if the diversion to the common adversary is challenged by a critic, this challenge can be construed as itself a compliance with the enemy's wrongdoing. We have described this mechanism above as "strategic reversal", but what needs also to be emphasized is that it protects the ad adversarium diversion from exposure and constraint to return to the issue at hand. The ad adversarium move is in this way self-reinforcing, widening the circle of "the enemy" it diverts to so as to include the opponent who objects to the diversion. If the law of proportionality has been aptly conformed to, and a suitably despised common ad- versary invoked, then there may be no escaping the trap: for whoever rebuts the move is himself or herself then open to attack as a dupe or advocate of the enemy. By this second operation the ad adversarium fallacy fortifies itself against counter-argument to the first, and entrenches the irrelevant position to which it has re-routed discussion by means of the very objections to it. The logic of defense here is such that it feeds on all attempts to rebut it. Whoever opposes the battle against the adversary provides occasions for those who wage it both to prove the superior virtue of their position and the unreliability of those who dissent from it.

We may express this self-reinforcing logic of the ad adversarium fallacy in this way:

1. In response to an issue, $\mathbf{A}$, discussant $\mathbf{x}, \mathbf{y}$ or $\mathbf{z}$ refer to the properties or behaviour of a common adversary, $\mathbf{E}$, who is neither logically nor causally relevant to $A$.

2. (i) $\mathbf{X}, \mathbf{y}$ and $\mathbf{z}$ and their audience concur with the attack on E or

(ii) $\mathbf{x}, \mathbf{y}, \mathbf{z}$ or another objects to attack on $\mathbf{E}$;

3. If 2 (i), the attack on E successfully diverts the issue to common ground; If 2 (ii), the objector to the attack on $\mathbf{E}$ is placed on $\mathbf{E}^{\prime} \mathrm{s}$ side, calling forth further attack on $\mathbf{E}$ and further fortification of the E-attacker's position against objection to it.

The most common current example of this operation of the ad adversarium diversion occurs when a superpower's international aggressions or other wrongdoings are challenged within the superpower's own domain of cultural influence or control. The reprehensible character or actions of the superpower's adversary, though irrelevant, are, in reply, invoked to redirect attack onto the other side (for example, denunciation of the U.S.S.R.'s actions 
in Afghanistan or Poland to answer criticism of U.S. actions in Central or South America). This pattern of diversion is so common as to be ideologically automatic, but it remains unidentified as a fallacy, and is even admitted into discourse as a praiseworthy concern for "consistency" and "fairness". This latter move still further ensconces the position of the ad adversarium digression. It adds to the virtue of upstanding opposition to the common adversary, legitimation by perceived intellectual honesty which, by conversion, is negated of the pursuer of relevance of claim who does not follow suit by switching to attack on the enemy. In this manner, the ad adversarium fallacy can so buttress its diversion with assaults on the common foe and any who object to it that its position becomes invulnerable to protest or correction.

What endows this diabolus ex machina with its underlying power is that social self-definitions typically presuppose adversarial other(s) upon which dishonest argument can predictably depend for diversionary appeal. To be American is to be anti-communist. To be Soviet is to be anti-capitalist. And so on, with, in the current geography of social determination by negation, the rest of the world's peoples largely deriving their social and political identity from these basic adversarial equations. Any resistance to such self definition can then be read as support of the enemy one is supposed to oppose, and indeed why this enemy must be attended to: its representatives are everywhere. This adversarial logic of social self-identity, whatever it might be, constrains its bearers to conform to it as members of their group. If they do not, they may be ostracized or, at worst, perceived as "subversives" and persecuted or killed. The ad adversarium fallacy in this way reposes on a very ontological structure, on an a priori form of social being-being against the designated enemy. The power of the fallacy lies not only in its group-empowered capacities for strategic reversal, diver- sionary escalation and self-reinforcement, but in the underpinning social basis of these that exists in any communication context which has not rationally prepared itself for the seductions of in-group/out-group division.

\section{The Argumentum ad Adversarium as Primary}

The fallacy of ad adversarium may, as we have seen, be founded on an a priori propensity to defend by social attack rather than by relevant argument. Attacking the enemy to justify oneself. We are familiar with this structure of response in other arguments of the ignoratio elenchi type-the ad baculum and ad hominem, for example. Often indeed these kinds of truthvalue-irrelevant digression are stacked one on top of the other in the same attack process. For example, a defender of a national government or powerful vested interest may reply to criticism of the government's repressive policies or of the vested interest's unconcern for public wellbeing, with a rousing denunciation of "terrorism" or "totalitarian socialism": thereby diverting the focus of argument from reply to the criticism to accusation against a standard adversary, who may not in fact be remotely involved. Because the force of public vilification, reduced social respectability or employability, vulnerability to state surveillance and the like may cause anyone inclined to press the claim to be "frightened off" its pursuit, we have here, lurking in the cognitive shadows, a fallacy of ad baculum as well, backing up the ad adversarium fallacy with an implicit appeal to force.

We can see without too much difficulty how still other types of ignoratio elenchi might fall into step behind the ad adversarium appeal: the ad hominem ("you must be one of them"), ad populum ("unlike you, we stand up for our society's freedom"), ad misericordiam ("you are going to bring disgrace on your family by talking this way") and ad verecundiam ("our own elected government/business leaders/ 
doctors could surely do no such wrong as you claim").

The underlying influence of the adadversarium, however, does not end with the ignoratio elenchi form. It empowers the appeal of other general fallacies as well, operating as their means to entice approval of their own devious routes of argument. For example, arguments by faulty analogy ("disarmament would be like the road of appeasement at Munich"), straw man ("People opposed to capital punishment care more for the criminal than the victim"), dubious assumption ("Since dope-smokers are a danger to society, the criminal law against them must be upheld"), non-sequitur ("The insurgents are Marxist-led, so they must be against democracy"), and so on, are all specially able to mislead when they invoke common dislike or hatred of some established antagonist. And as we have noted too with the guilt-by-association, scapegoating and other argument ploys, their appeal is most effective when based on what is, in truth, an ad adversarium assault on a recognizable group enemy. We are dealing here, in short, with a kind of metaphysical disorder underlying a host of fallacious argument attacks and counter-attacks in whose distinct appearances our analyses have hitherto remained confined.

What is most important about the ad adversarium appeal is that it may be the "prime mover" of a whole system of irrational appeal: the underlying track-switch of thought that turns us from relevant reason to attack against some convenient Other, upon which UsThem underpinnings an edifice of further irrelevant appeals to reputation, sentiment, authority, fear and so forth may be standardly if implicitly founded. For this reason, we need to become formally aware of the ad adversarium move, even mind-set, wherever it occurs. The displacement of critical predication onto the "enemy" has become, we might say, the great redherring of our civilization's discourse, and may subvert us from the path of reason more deeply and perilously than any other fallacy we know.

\section{Notes}

[1] Ignoratio elenchi means, literally, "ignorance of refutation". The term arises as a Latin translation of Aristotle's name for one of the thirteen fallacies he describes in De Sophisticis Elenchis, and has covered a wide range of logical sins since. For example, C.L. Hamblin, Fallacies (New York: Methuen, 1970) pp. $41 \mathrm{ff}$, lists fully 24 species of this fallacy and Alex Michalos, Improving Your Reasoning (Englewood Cliffs, N.J.: Prentice-Hall, 1970), pp. 50-67, lists 21. (I am indebted to David Hitchcock here.) All such noted species of the ignoratio elenchi, however, conform to the unifying principle we cite.

[2] We use the phrases "common adversary", "conventional foe", "customarily shared opponent" and so on interchangeably. What qualifies a party or entity, $\mathbf{E}$, for the status referred to by these and similar expressions is that the social group, $\mathbf{G}$, with in whose context $\mathbf{E}$ is invoked, has as a group a predictable tendency to attack E. It is consistent with this description that some individual members of $\mathbf{G}$, whether $\mathbf{G}$ is a national television audience or a living room gathering, may as individuals dissent from G's disposition to attack $\mathbf{E}$. (It would be a fallacy of division to infer the contrary.) It also follows that in some cases, say, "big unions", "women's libbers", or "student radicals", G's collective reaction to invocation of these as $E$, will vary from $\mathbf{G}$ to $\mathbf{G}$, depending on the composition of the group appealed to. (The "common adversary" here will be predictable for some groups, business or con- 
servative, but not predictable for others.) It is these complicating factors that can account for cases of the ad adversarium's dramatic failure (e.g. hisses from the audience), or change of adversarial objects over time with the same group.

[3] Details of the World Court's decision are drawn from Professor Edward McWhinney's Letter to the Editor, "Full Circle", Clobe and Mail, October 25, 1985, p. 7.

[4] "Sikh separatist leader denies C.I.A. aid", Globe and Mail, November 3, 1984, p. 15.

[5] "Equal opportunity scheme likened to McCarthyism", Globe and Mail, April 17, 1984, p. 10.

[6] "Baptist crusader would rein in cosmopolitan living", Clobe and Mail, January 2, 1986, p. A 18.

[7] Reported in "Marcos to ignore 'crazy' allegation of bogus war record", Associated Press, January 24, 1986.

[8] For a more detailed description of the "two wrongs" fallacy, see Ralph H. Johnson and J. Anthony Blair, Logical Self-Defense (Toronto: McGraw Hill Ryerson, 1983) pp. 102-107. For a more restricted account, see Leo Croarke, "When Two Wrongs Make a Right" (Informal Logic Newsletter, December 1982 (Vol. 5, No. 1) pp. 10-13. The distinctions I set out below between the "two wrongs" and ad adversarium fallacy hold for all versions reported in these accounts.

[9] Cited in Stephen Handelman, "Peace is Political Prisoner",
Toronto Star, December 14, 1985 , p. A 14.

[10] There have been numerous accounts of this type in contemporary scholarly analysis of Latin American, Middle East, African and Asian affairs. For clear English-speaking examples, see Noam Chomsky and Edward S. Herman, The Political Economy of Human Rights, Volumes I and II. (Montreal: Black Rose Books, 1979), Lise North, Better Crounds: The roots of Revolt in El Salvador (Toronto: Between the Lines Press, 1982), Edward S. Herman, The Real Terror Network (Boston: South End Press, 1983), and Don Cockburn (ed.), An Anti-Intervention Handbook: Canadians and the Crisis in Central America (Toronto: Latin American Working Group, 1985).

[11] See Richard Paul, "Teaching Critical Thinking in the 'Strong' Sense: A Focus on Self-Deception, World-Views, and a Dialectical Mode of Analyses", Informal Logic Newsletter, May 1982 (Vol. IV, No. 2), pp. 2-7. For explanation of the decisive importance of social contexts and customary belief systems in providing the underlying source of the ad adversarium's diversionary lure, see the last two sections of this paper.

* I am grateful to Brian Calvert, David Hitchcock, Alex Michalos and the editors and referees of Informal Logic for their helpful ciriticisms and comments on earlier drafts of this paper.

Prof. John McMurtry, Department of Philosophy, University of Guelph, Guelph, Ontario, Canada, N1G 2W1 